University of Chicago Law School

Chicago Unbound

Journal Articles

Faculty Scholarship

2002

\title{
A Rational Basis for Affirmative Action: A Shaky but Classical Liberal Defense
}

Richard A. Epstein

Follow this and additional works at: https://chicagounbound.uchicago.edu/journal_articles

Part of the Law Commons

\section{Recommended Citation}

Richard A. Epstein, "A Rational Basis for Affirmative Action: A Shaky but Classical Liberal Defense," 100 Michigan Law Review 2036 (2002).

This Article is brought to you for free and open access by the Faculty Scholarship at Chicago Unbound. It has been accepted for inclusion in Journal Articles by an authorized administrator of Chicago Unbound. For more information, please contact unbound@law.uchicago.edu. 


\title{
A RATIONAL BASIS FOR AFFIRMATIVE ACTION: A SHAKY BUT CLASSICAL LIBERAL DEFENSE
}

\author{
Richard A. Epstein*
}

I am honored to participate in a symposium on the occasion of the 100th anniversary of one of America's preeminent law reviews. I am saddened, however, to write, at what should be a moment of celebration, with the knowledge that both the Law School and the College of Literature, Science and the Arts are enmeshed in extensive litigation over the critical and explosive issue of affirmative action.

To find striking evidence of the deep split of learned judicial views on this issue, it is necessary to look no further than the sequence of opinions in Gratz v. Bollinger ${ }^{1}$ and Grutter v. Bollinger. ${ }^{2}$ Gratz was bought by a rejected white applicant to the College of Literature, Science and the Arts; Grutter by a rejected white applicant from the Law School. The two district courts reached opposite conclusions on what they perceived to be the central issue in this running dialogue: did the racial diversity of the student body count as a compelling state interest that justified a departure from the color blind norm established under the equal protection clause of the Fourteenth Amendment? Diversity, at the district court level, counted as a compelling state interest for the University of Michigan College of Literature, Science and the Arts, but not for its Law School. This division of opinion was erased when Grutter was reversed on appeal, most fittingly, by a bare five to four majority. ${ }^{3}$ No one seriously thinks that the matter will rest here, for the tensions within the Sixth Circuit and beyond make it likely that at long last the Supreme Court will revisit this issue.

But what approach should be adopted to respond to this question? It is generally assumed that the legal answer lies in parsing the deci-

* James Parker Hall Distinguished Service Professor of Law, University of Chicago; Peter and Kirsten Bedford Senior Fellow, The Hoover Institution. A.B. 1964, Columbia; B.A. (Juris) 1966, Oxford; LL.B. 1968, Yale. - Ed.

1. 122 F. Supp.2d 811 (E.D. Mich. 2000).

2. 137 F. Supp.2d 821 (E.D. Mich. 2001), rev'd 288 F.3d 732 (6th Cir. May 14, 2002).

3. Grutter v. Bollinger, 288 F.3d 732 (6th Cir. 2002). The case was marked by a sharp procedural dispute over the propriety of the en banc decision. For the attack on the procedure, see Grutter, 288 F.3d at 810-14 (Boggs, J., dissenting), responded to in Grutter, 288 F.3d at 752-58 (Moore, J., concurring) and Grutter, 288 F.3d 772-73 (Clay, J., concurring). I take no position on this dispute. 
sions of two key Supreme Court precedents: Regents of University of California v. Bakke $e^{4}$ and Adarand Constructors, Inc. v. Pena. ${ }^{5}$ Divining these precedents offers ample grist for the legal mill, but is no part of my self-appointed task. Rather, I propose to outline in some detail the approach that I would take to these questions on the assumption that the only tools in the toolbox were the bare Constitutional text and a general appreciation of the Constitution as a classical liberal document, that is, that emphasizes limited government, strong protection of property rights and contractual freedoms, coupled with prohibitions against force and fraud on the one hand, and monopoly power on the other. $^{6}$

Many people would assume, wrongly, that this systematic view of the Constitution leads to an invalidation of all affirmative action programs. But I believe that the sounder implications run in the opposite direction. Within this framework, I believe that both district courts and the Sixth Circuit went off the rails when in common they held that the right question only asks how to apply the strict scrutiny test to the Michigan affirmative action program. I believe that this is the wrong standard of judicial review, one which should be abandoned in favor of a more flexible standard that measures the constitutionality of the Michigan program by comparing it with the practices done by private, competitive institutions on a voluntary basis. Using that standard, my ultimate conclusion is that the University of Michigan, acting on its own initiative (a qualification that matters), is within its rights under the Constitution to establish an affirmative action program, however wise or foolish its decision.

To many individuals that position seems out of character with my reputation for being "conservative" on various issues of social policy. But the label "conservative" often elides differences between social conservatives on the one hand ${ }^{7}$ and individuals like myself that work within the classical liberal tradition. Within that tradition, I shall outline the set of beliefs that leads me to this conclusion. The path will, however, both zig and zag. My first order of business is to indicate why the claims for affirmative action fail under the current law so long as it requires the state to produce some form of compelling state interest test to justify affirmative action programs. My second order of business is to explain how I think that the law should be restructured so as to permit the use of affirmative action programs in public universities.

4. 438 U.S. 265 (1978).

5. 515 U.S. 200 (1995).

6. So defended in Richard A. Epstein, Takings: Private Property and the POWER OF EMINENT DOMAIN (1985).

7. See, e.g., ROBERT H. BORK, SLOUCHING TOWARdS GOMORRAH: MOdERN LIBERALISM AND AMERICAN DECLINE (1996). 


\section{Compelling State Interest}

The common theme in all the opinions in Grutter and Gratz is that the University of Michigan must show a compelling state interest in order to maintain its affirmative action policies against challenges under the equal protection clause. As was stated in Adarand, "all racial classifications, imposed by whatever federal, state, or local governmental actor, must be analyzed by a reviewing court under strict scrutiny. In other words, such classifications are constitutional only if they are narrowly tailored measures that further compelling governmental interests." ${ }^{\prime \prime}$ In its decision, the majority of the Sixth Circuit added this gloss to the Adarand test:

[I]n applying strict scrutiny, we cannot ignore the educational judgment and expertise of the Law School's faculty and admissions personnel regarding the efficacy of race-neutral alternatives. We are ill-equipped to ascertain which race-neutral alternatives merit which degree of consideration or which alternatives will allow an institution such as the Law School to assemble both a highly qualified and richly diverse academic class. ${ }^{9}$

That clarion-call for deference does not square well with the traditional conception of strict scrutiny. But the majority of the Sixth Circuit undoubtedly added that gloss because it could not unilaterally overturn the strict scrutiny standard in Adarand. In one sense, that tactical judgment was surely correct, for no matter what one thinks of the desirability of affirmative action programs, one conclusion seems clear. Under its traditional rendering, the strict scrutiny standard dooms the race-sensitive programs of the University of Michigan.

The first point is that the University of Michigan does, for better or worse, take race into account in an explicit fashion in making its admissions decisions. The statistical evidence of racial preferences offered by the plaintiff's expert, Dr. Kinley Larntz, in Grutter centered on the "relative odds of acceptance" for members of each racial group. The technique is simplicity itself. All that is needed is to divide the applicants of all races into various cells, measured by their common grades and board scores. One then compares the probabilities of admission for members of the different groups. These differences are too large and too persistent to be obtained by chance. Judge Friedman found, for example, that "[i]n 1995, the relative odds of acceptance were 61.37 for Native Americans, 257.93 for African Americans, 81.90 for Mexican Americans, and 37.86 for Puerto Ricans." 10 Judge

\footnotetext{
8. 515 U.S. at 227.

9. Grutter, 288 F.3d at $750-51$.

10. Grutter, 137 F. Supp.2d at 837 n.20.
} 
Friedman rightly dispatched the statistical evidence that Dr. Gerald Raudenbush offered for the University of Michigan in short order. ${ }^{11}$

The Michigan programs (like those of virtually every other public university) thus deviate from the prima facie color-blind constitutional norm. The only question left to argue is that of justification. On this score, conventional wisdom rightly divides the purported justifications into two classes. The first of these holds that race sensitive programs can be used to provide remedies to particular and identifiable individuals who had been victims of discrimination wrought by the defendant institution at some earlier time. The clear effort here is to appeal to some implicit notion of Aristotelian corrective justice under which the individuals to whom the relief is extended are the same persons who were wronged by the system in the first place. ${ }^{12}$

That rationale, however, has a built-in time fuse that makes it a wasting asset in equal protection (or other race-based constitutional) litigation. The last use of official discrimination in the United States ended thirty-eight years ago; the vestiges of that discrimination may well have lingered on a bit longer. But these remedial claims by definition get weaker with each passing year even in those states that practiced some form of racial segregation or exclusion. ${ }^{13}$ But Michigan was not one of those places, and no amount of self-slander could make it so. Unless the University of Michigan can wrap itself in past sins that it did not commit, this backward looking rationale is dead on arrival. There is no need to discuss it further.

The forward looking rational takes a different tack: diversity. ${ }^{14}$ The argument in a word is that the educational experience is better for all concerned if students are exposed to students who are drawn from all walks of life. It is just this line of argument that the University advanced with unitary passion on its behalf. ${ }^{15}$ According to its expert witness, Dr. Pamela Gurin, an educational program that has few, if any, black or other minority students in it offers a weaker education for the white as well as the other minority students in the program. ${ }^{16}$ Diversity is not tied to past sins, so it is not a wasting asset. But for

11. Id. at 839 .

12. See ARISTotle, The Nicomachean ETHICS, Book V, 1131b-25 et seq. (H. Rackham trans., Harvard University Press reprint ed. 1982).

13. For my views on this in connection with litigation on local school districts, see Richard A. Epstein, The Remote Causes of Affirmative Action, Or School Desegregation in Kansas City, Missouri, 84 CAL. L. REV. 1101 (1996), discussing Missouri v. Jenkins, 510 U.S. 70 (1995).

14. For discussion, see, for example, Kathleen M. Sullivan, The Supreme Court, 1986 Term - Comment: Sins of Discrimination: Last Term's Affirmative Action Cases, 100 HARV. L. REV. 78 (1986).

15. Grutter, 137 F. Supp.2d. at 825-36; Gratz v. Bollinger, 122 F. Supp.2d 811, 822 (E.D. Mich. 2000).

16. Gratz, 122 F. Supp.2d. at 822-23. 
some purposes diversity is a trope that may sweep too broadly, for it allows, indeed requires, the accommodation of all minority groups, not just blacks who have nationwide suffered the stain of slavery and past discrimination. But even if it is restricted to blacks only, and even if the social science is treated as solid, the evidence presented does not come close to being the required compelling state interest, at least under any neutral standard that treats discrimination against whites with the same earnest apprehension as it does discrimination against blacks. By way of comparison, think of how difficult it is today under Title VII for any employer to show that he has a bona fide interest in discriminating on the grounds of sex or national origin. ${ }^{17}$ The statute did not even consider the possibility that such a justification could be offered on reasons of race. ${ }^{18}$ The original legislative history to Title VII may have provided that it is permissible for French restaurants to hire French chefs, ${ }^{19}$ but the case law under Title VII has been unrelenting insofar as it has required a strict proof of business necessity to sustain any explicit sex classification. ${ }^{20}$ It is difficult, for example, to argue that states should have only female guards in female prisons. ${ }^{21}$ The argument is that differences in sex are not to be tolerated unless the heavens will fall.

Racial classifications are, if anything, more difficult to justify. Title VII hints at that difference because it contains no bona fide occupational qualification ("BFOQ") for race. Here, moreover, the heavens will not fall even if every program of race-based preferences were repealed tomorrow. Start with the most obvious point: Students of minority groups may be forceful and eloquent spokesmen for their own racial views. But so what? There are many academic courses in which the questions of race and sex are marginal at best. In the arts and sciences, none of the math and science curriculum has a racial message; the same is true of large portions of social sciences and the humanities as well. Within the law school, tax, business, and procedural courses have little if any content related to race, and it would be odd to say that they could not be taught successfully without any reference to race, or indeed without any minority or female students. After all,

17. See Civil Rights Act of $1964, \S 703$ (e), codified in 42 U.S.C. $\$ 2000 \mathrm{e}-2$ (1994) (allowing bona fide occupational qualifications for religion, sex and national origin). For my views, see Richard A. EPSTEIN, Forbidden Grounds: The CASE Against EMPloyment DISCRIMINATION LAWS 283-312 (1992) [hereinafter EPSTEIN, FORBIDDEN GROUNDS].

18. Id. (race not on list).

19. As stated in the Clark-Case memorandum in support of the Civil Rights Act. 110 CONG. REC. 7213 (1964).

20. See, e.g., Int'l Union, UAW v. Johnson Controls, Inc., 499 U.S. 187 (1991).

21. See, e.g., Torres v. Wisconsin Dep't of Health and Social Servs., 838 F.2d 944 (7th Cir. 1988) (rejecting practice), overturned en banc, 859 F.2d 1523 (7th Cir. 1988) (reversing decision below). 
many of the lawyers and professors who teach today received excellent education in these subjects before the advent of any affirmative action program.

Of course other courses have greater racial content. Colleges of Arts and Sciences do teach extensive programs in Black Studies, and much of the humanities and social science curriculum does revolve around the issue of race. Similarly in law school, many courses, such as criminal procedure, civil rights, constitutional law, and employment discrimination positively invite some distinctive racial point of view. But once again, where is the compelling state interest? It would be odd to think that minority outlooks represent some monolithic front organized by race. We should expect a divergence of opinion both within and across racial groups. The members of a particular racial group never hold a de facto monopoly on any matter of public debate. It is, to say the least, highly improbable that all the white students in a large class are so ignorant of race relations that they are unable to comprehend the worries and aspirations of minority group members. Indeed, to insist that they cannot express this point of view suggests ominously that they cannot internalize that point of view either, even when from members of minority groups. But if that is the case, then diversity can hardly count as a compelling state interest if it consistently fails to teach white students enough so that they can impart what they learn to others.

Fortunately, this observation is wishful thinking. In the pre-1964 era, the entire civil rights movement succeeded only because large numbers of white people, many of whom were raised in segregated circumstances, backed the movement with their hearts and souls, and in some cases their lives. Although not minority members, these people can relate their own experiences, and even if they cannot, it is easy to assign readings, or invite guest lecturers to express the black point of view. I do not claim that the use of any of these approaches works as well as a program that has a minimum minority representation in each class. But it is wholly unnecessary at this point to undertake that battle. The question here is not whether education works better with diversity, on which people can, of course, disagree. It is whether the state has a compelling interest in that direction. A compelling state interest is one that says we should rely on racial classifications to prevent race riots. No way, at least not under any two-way, color-blind standard articulated in Adarand.

The color-blind standard, if conscientiously applied, cuts even deeper. One effort to deal with the demands for affirmative action after the Fifth Circuit's decision in Hopwood v. State of Texas, ${ }^{22}$ which struck down the affirmative action program in Texas universities, is

22. 78 F.3d 932 (5th Cir. 1996). 
illustrative. In order to maintain black enrollment in Texas universities, Texas adopted a system whereby automatic admission was guaranteed on a color-blind basis to the top ten percent of each graduating class of each Texas high school. The program was color-blind in form, but its explicit intention was to maintain the levels of enrollments of minority students. The program was, in Glenn Loury's terms, colorblind but not color indifferent. ${ }^{23}$ The point here is to avoid the visible sting associated with explicit racial categories while obtaining as much of the preferred race-distribution as possible, given that the top ten percent of an all-black high school for example has to be by definition black, no matter what the qualifications of the students in that top decile.

There are forceful objections to the use of this race-blind (but not race indifferent) system as a matter of policy. Oftentimes black students with lower class standing from rigorous urban schools have superior academic credentials to black students who graduate at the top of smaller and less rigorous high schools. In principle, a sensible affirmative action program should take the strongest African-American students, a result that can only be achieved by the use of raceconscious standards. Texas's new practice just illustrates the old maxim of Karl Llewellyn that covert tools are bad tools. But for these purposes, pass those difficulties by, for this formal system of raceneutrality has to count as an open-and-shut evasion of a strict scrutiny test, precisely because of its hidden racial agenda. The civil rights laws knew of the dangers of neutral laws with disparate impact. The old grandfather laws were efforts to stymie black participation in the political process by denying the vote to anyone whose grandfather was not eligible to vote in, of course, the antebellum South. If one point was made repeatedly clear in the framing of the Civil Rights Act of 1964 , it was that the federal statute would offer but a puny barricade to racial discrimination if it only attacked explicit racial classifications while enforcing neutral classifications adopted with the specific motive of keeping blacks out of certain positions. ${ }^{24}$ Indeed, even the use of motive-based tests was adjudged insufficient for that purpose, so that by 1971 the United States Supreme Court held that any employment practice done without racial motive could be attacked under Title VII so long as it had a disparate impact, unless that result could be justified by some narrow conception of business necessity. ${ }^{25}$

The ten percent rule is, of course, adopted with the explicit racial motive of maximizing black enrollments at the university level. If

23. GlenN C. Loury, THE ANATOMY OF RaCial InEQuality 133 (2002).

24. See, e.g., McDonnell Douglas Corp. v. Green, 411 U.S. 792 (1973) (setting out the various disparate treatment tests to smoke out cases in which neutral language was a pretext for discriminatory outcomes).

25. See, e.g., Griggs v. Duke Power, 401 U.S. 424 (1971). 
Adarand means what it says in holding that strict scrutiny applies both ways, then this program that rejects racial indifference should be condemned as vigorously as a literacy test or a grandfather clause that is designed to keep black voters from the polls. Under strict scrutiny, facially neutral statutes and programs fall instantly to equal protection challenges when they are motivated by an explicit desire to favor whites over blacks. There is some dubious authority that extends the prohibition even to statutes whose intention is to restore or validate the common law rules that allow all property owners (common carriers excepted) to decide whom to deal with and whom not ${ }^{26}$ We cannot just forget these doctrinal byways if we believe in strict scrutiny for all race-based challenges. Let the games be played under the current constitutional rules, and affirmative action is history.

This view should come as no surprise to anyone who has glanced at the interpretive history of the clause. We can find only one case that sustained government action under this framework, Korematsu $v$. United States, ${ }^{27}$ which upheld the Japanese internment during World War II, even after all risk of a Japanese invasion of the West Coast had long passed. Surely that case offers cold comfort for the defenders of affirmative action: indeed government victories serve to remind us that strict scrutiny really does have some irreducible place in any sound analysis of equal protection. But for these purposes Korematsu is the dubious exception, not the general rule. Before the recent round of affirmative action cases, the Supreme Court adhered to the famous formulation of Professor Gerald Gunther who observed that this standard was "strict" in theory, but "fatal" in fact ${ }^{28}$ Fairly apply strict scrutiny and Michigan's affirmative action program is as dead as a doornail. True, but wholly unacceptable. We have to begin afresh.

\section{Rethinking the Constitutional Standard: Symmetry?}

The only question worth asking is, in my view, how to dislodge this strict scrutiny test in these affirmative action battles, without necessarily jettisoning it in any and all contexts to which it might apply. In order to do that we have to recall how and why the test developed in the first place. As a matter of doctrinal convention, the strict scrutiny test lies at the opposite pole from the badly misnamed "rational basis" test, under which the level of deference accorded to the legislature is

26. Reitman v. Mulkey, 387 U.S. 369 (1967).

27. 323 U.S. 214 (1944).

28. Gerald Gunther, The Supreme Court, 1971 Term - Foreword: In Search of Evolving Doctrine on a Changing Court: A Model for a Newer Equal Protection, 86 HARV. L. REV. 1, 8 (1972). 
so vast that any bad argument asserted with a straight face prevails. ${ }^{29}$ One might say that the test is "rational" in theory and "permissive" in fact. No legal system, of course, could operate only at these two extremes, so a test of intermediate scrutiny has insinuated its way into the mix in equal protection law, as elsewhere. Our Constitution has an embarrassment of riches: a standard of review for every pocketbook and taste.

Focusing for the moment at the extremes, what accounts for the spread of judicial sentiment to multiple challenges under the same clause? What factors could prompt the Supreme Court to take such a radically different attitude to different forms of legislation under the same constitutional provision? Obviously, no simple textual answer will explain the migration to two extremes simultaneously. Some structural or functional explanation has to be added to the mix. That explanation has both a procedural, or at least process-based, and a substantive component. Thus the first key variable is the level of trust that the Court perceives as appropriate for the political branches of government in any given context. The second variable is whether the Court is able to form its own considered view of whether the laws in question make sense on substantive grounds.

The rational basis test is used when that level of trust is high, and the Court has no strong conviction one way or the other on the substantive merits of the laws before them. It is unfortunate that the Supreme Court overlearned from the "mistake" of Lochner $v$. New $Y_{o r k}{ }^{30}$ in holding that virtually all general legislation directed to economic affairs lies outside the scope of judicial review, not only under the equal protection clause, but just about everywhere else as well. Whether the issue was substantive due process or takings, or even matters relating to the scope of the commerce clause, the Court gravitated toward the rational basis test because it held, and still holds, the perception that the political branches of government, both state and federal, can effectively deal with the economic issues that challenge the nation. It has no strong views as to what counts as sound economic policy. In an earlier age, such questions as the choice between monopoly and competition had merited judicial intervention in favor of the later. ${ }^{31}$ The welter of New Deal experiments championed monopolies in some cases (as agricultural policy, such as that sustained in United

29. See, e.g., Williamson v. Lee Optical, 348 U.S. 483 (1955); Ry. Express Agency v. New York, 336 U.S. 106 (1949) (upholding restrictions on advertising under due process).

30. 198 U.S. 45 (1905).

31. See, for example, the cases striking down wage and price regulations in those industries not "affected with the public interest." See, e.g., Wolff Packing Co. v. Court of Indus. Relations, 262 U.S. 522 (1923) (effectively overruled in Nebbia v. New York, 291 U.S. 502 (1934) (sustaining minimum prices for milk)); United States v. Cohen Grocery Co., 255 U.S. 81 (1921). 
States v. Wrightwood Dairy Co. ${ }^{32}$ and Wickard v. Filburn ${ }^{33}$ ) and competition in others (as with vigorous enforcement of the antitrust laws), except of course against state sponsored cartels. ${ }^{34}$ In principle, national legislation veered strongly for and strongly against competition simultaneously. Only the legislature could sort through the confusion after all the relevant interest groups had participated in the legislative process, where they could protect themselves against various forms of political risk. ${ }^{35}$ The standard of rational basis review was thus borne of two parallel considerations. First, the Court no longer had any substantive view of what counts as good legislation on economic matters. Second, the Court thought that an open political system gave the various actors all the process protection needed to avert unacceptable outcomes. The revolution of 1937 cemented this synthesis into place.

Yet this happy state of affairs was not to last. Just as the Court went into rapid retreat on economic issues, questions of race surged to the fore. In these cases, both the assumptions propping up the rational basis test collapse, and the famous footnote 4 in the Carolene Products decision immediately reinstituted a higher standard of review in favor of discrete and insular minorities, ${ }^{36}$ a code phrase, which at a minimum included black citizens in the South. Any claim that all relevant parties could protect their interests through the political process was patently false for a disenfranchised black minority. So overcoming its shaky start with the first white primary cases, ${ }^{37}$ the Court's basic attitude quickly shifted to using strict scrutiny to test legislation on matters of race. The Court did not have to engage in complex economic calculations to determine the evils of segregation and Jim Crow. It also recognized that the political process was rigged to frustrate the redress of individual and group grievances. Those perceptions thus drove the Court to demand the most compelling justifications of any restriction on individual liberties based on race. As with the rational basis test, the overall attitude spoke volumes. The peculiar features of each specific constitutional clause counted for relatively little. Tough scrutiny with race cases was rightly the order of the day.

One of the great ironies with the modern statement of strict scrutiny is that it erects a color-blind norm that runs in both directions, such that under its relentless Adarand formulation any claim brought

32. 315 U.S. 110 (1942).

33. 317 U.S. 111 (1942).

34. See, e.g., Parker v. Brown, 317 U.S. 341 (1943).

35. See Richard Stewart, The Reformation of American Administrative Law, 88 HARV. L. REV. 1669 (1975).

36. United States v. Carolene Products Co., 304 U.S. 144, 152-53, n.4 (1938).

37. See, e.g., Smith v. Allwright, 321 U.S. 649 (1944) (invalidating white primary); Grovey v. Townsend, 295 U.S. 45 (1935) (sustaining white primary). 
by a white person against state action should be judged by the same exacting standards as any claim brought by a black person against state action. Clearly, there has been an enormous shift in political institutions and political behavior since the end of the Second World War, indeed, even since the passage of the Civil Rights Act of 1964. But with all the advances in the protection of minority interests, with all the trumpeting of a new generation of explicit racial preferences, no one could say, or at least say honestly, that whites today are excluded from the political process as blacks had been under segregation; nor, in light of an oft-painful racial history, is it possible to subject raced-based polices that benefit blacks to the same full-throated denunciation as could be brought against state-sponsored segregation. To be sure, some people do believe that the color-blind principle operates as a categorical imperative good for all ages. They can insist that the principle that first reared its head in Justice Harlan's classic dissent in Plessy v. Ferguson, ${ }^{38}$ showed its value in the war against segregation, and could do every bit as much good in rooting out affirmative action programs. But such fervor is sadly misplaced: the simple truth is that the division of learned and responsible opinion makes it impossible to denounce affirmative action as the second-coming of Jim Crow. It is always open, in a popular if not a constitutional sense, to argue that affirmative action should be a response to the prior evils of segregation. It is hard to find some prior historical practice that could be invoked as the justification for Jim Crow segregation.

\section{Toward Rational Basis Review}

We thus arrive at an unhappy impasse. If we hew to traditional constitutional law doctrine, then we must jettison affirmative action notwithstanding its widespread support in the university and business communities..$^{39}$ Their political position does not represent solely some high sense of social purpose. It also represents a strong instinct for institutional survival. The disparate impact tests used under Griggs represent that extravagant overextension of Title VII, which itself should be repealed. Businesses know that it is possible to live with Griggs, albeit not cheaply, solely because there is so little private insti-

38. 163 U.S. 537 (1896).

39. See, e.g., Gratz v. Bollinger, 122 F.2d 811, 822 n.11 (E.D. Mich. 2000). See also the corporations: General Motors, Abbott Laboratories, Bank One Corp., E.I. Dupont de Nemours Co., Dow Chemical Co., Eastman Kodak Col., General Mills, Inc. Intel Corp., Johnson and Johnson, Kellogg Co., KMPG Int'l, Lucent Technologies, Inc. Microsoft Corp., PPG Industries, Inc., Procter and Gamble Co., Sara Lee, Crop., Texaco, Inc., TRW, Inc. Id. at 813. See also, the ExxonMobil advertisement in the New York Times, March 7, 2002, at A31, "Laborious indeed at the first ascent," whose insert proclaims "Business support for women and minorities is growing." The ad is one of a series that proclaims all the race and sex-based programs that business supports, and praises per se violations of the color-blind, sex-blind standards of the Civil Rights Act of 1964. 
tutional sentiment in favor of reverse discrimination in the first place. But the systematic extension of Griggs under a rigorous both-ways standard not only means the end of every affirmative action program in the private sector, but also a ceaseless round of suits any time the composition of the workforce deviates from Griggs's insanely tight requirements of proportionate representation. Businesses and universities have little patience with the aesthetic niceties of perfect symmetry under a high standard. What they crave is freedom to enact the policies that they care about, and toward that end they get far more running room in a world in which Griggs becomes a one-way test and courts acquiesce in most if not all affirmative action practices.

The same political calculations carry over to the equal protection clause. What is desired by these businesses and universities under the equal protection clause is the same partial dispensation from the legal straightjacket. Strong norms that ban racial discrimination against blacks are acceptable in principle, but the both-ways test is every bit as suicidal for American public institutions as the both-ways tests under Griggs are for private firms and universities. Clearly, something is very odd about judicial intrusion into the oversight of affirmative action, for no one believes, on or off the courts, that the factual predicates that justified strict scrutiny for legislation directed against disadvantaged black citizens applies with equal force to legislation in favor of disadvantaged black citizens. We do not have disenfranchised white voters; we do not have white-only fountains, nor racial policies that stink at the nostrils.

\section{Back to First Principles, Briefly}

The question then is, how we can translate that simple insight about social differences, grasped by every administrator public and private, into sensible constitutional doctrine? I think that we should take our cue from the judgment and practices of our private institutions, most of which are committed to some level (but not necessarily the same level) of affirmative action in their daily operations. The argument requires us to attack some powerful mainstays of the modern civil rights movement, but since I have already sacrificed any and all claim to public office, I shall state the argument against the current status quo as best $I$ can as a matter of first principle..$^{40}$

The discussion starts with the relationship of the individual to the state. That question resists a frontal assault by the tools of public law alone. Instead we must proceed by indirection. We must first develop

40. For fuller statements of my position, see RICHARD A. EPSTEIN, PRINCIPLES FOR A FREE SOCIETY: RECONCILING INDIVIDUAL LIBERTY WITH THE COMMON GOOD (1998), and Richard A. EPSTEIN, SIMPLE RULES FOR A COMPLEX WORLD (1995). I shall not document the details of the argument here. 
a comprehensive theory that explains the relationship between ordinary individuals. That theory then supplies us with the needed baseline to understand the relationship between the individual and the state. How then do individuals relate to each other? In standard political theory, the original position in the state of nature offers scant comfort. Before law, each may do what he pleases to any other person, who in turn is free to respond in the same way. Some writers in the Hobbesian tradition call this unbounded self as the exercise of a natural liberty, but other writers distinguish sharply between liberty and license, and reserve the term natural liberty to refer to conduct that does more than fear retaliation by others, but respects their individual rights.

These ultimate descriptive differences about the state of nature are important for the history of ideas, but they should not conceal the essential point. The utter absence of any legal order precludes any articulated rights and duties that bind individuals to each other. Brute strength coupled with cunning determines how people interact with each other. The evident inconveniences of this social position have impressed themselves on all social contract theorists from Hobbes to Locke to Hume and Smith. Each writer in his own way concludes that the creation of a social order (or contract) requires all individuals to renounce the use of force (and fraud) against each other and the state to have enough power to make good the promises of the new legal order. Once that is done, then each is better off, for the security that he obtains is worth more than the liberties that he surrenders. Hence the first step of political theory is to postulate a series of universal rights whose correlative duties are to keep off. These duties benefit all and they bind all. They are imposed by law because of the manifest inability to achieve them by unanimous contract.

The next inquiry is whether we can conceptualize any further improvement in social arrangements from this new baseline. At least one move is easy to make. The renunciation of force allows people to keep what they have, but does not allow them to acquire anything through voluntary exchange: contracts, conveyances, gifts, mortgages, partnerships and the like are not part of the grand plan. But the introduction of a system of free exchange allows for gains from trade, which when applied systematically (that is over the full range of transactions) create vast improvements over the previous state of the world as well. Exchange is thus added to security. To that, we can add to the list of sensible state functions by allowing government to maintain the key network elements, such as roads and other network industries: again state power allows a social group to obtain output that cannot in practice be reached solely by voluntary combination.

The system reads like a wish list at this point because it makes no financial provision for the collective enforcement of these rights, and thus apparently relies on allowing each person to use self-help in the 
state of nature. The self-help system is so contaminated with bias and uncertainty that its drawbacks require little elaboration. Clearly, we can achieve an additional round of improvements by allowing for a system of (proportionate) taxation that supplies the funds to provide both the internal enforcement of these rights to liberty, property and contract, and protection against external enemies who might otherwise undermine the whole system..$^{41}$ The implicit corollary is that all citizens have an equal right to participate in determining the way in which those funds were spent on these collective functions. In four easy steps we reach the core principles of limited government. ${ }^{42}$

The question that one has to ask is what place does this system have for an antidiscrimination law that stipulates the grounds on which it is proper (or not proper) to do business with others. ${ }^{43}$ The answer is, I believe, that a nondiscrimination principle is a powerful antidote to the abuses of government and private power, where either is blessed with monopoly power over certain areas of human life. Such is the case when the state supplies protection to its citizens or essential services that cannot be obtained from other sources. The impartial administration of the rules of civil and criminal liability is indispensable protection for any system of ordered liberty. It is just for that reason that the first Justice Harlan struck a powerful chord when he appealed to the color-blind principle as a means to equalize legal position in the face of evident social equality. ${ }^{44}$ His object was to make

41. See, e.g., AdAM SMITH, The WEALTH OF NATIONS 777 (Mod. Lib. Ed. 1937) ("The subjects of every state ought to contribute toward the support of the government, as nearly as possible, in proportion to their respective abilities; that is, in proportion to the revenue which they respectively enjoy under the protection of the state.").

42. On this point, Adam Smith is most instructive:

According to the system of natural liberty, the sovereign has only three duties to attend to: ... first the duty of protecting the society from the violence an invasion of other independent societies; secondly, the duty of protecting as far as possible every member of the society from the injustice or oppression of every other member of it, or the duty of establishing an exact administration of justice; and, thirdly, the duty of erecting and maintaining certain public works and certain public institutions, which it can never be for the interest of any individual, or small number of individuals to erect and maintain.

Id. at 651 .

That this position does not contemplate the regulation of labor markets is seen by Smith's earlier observation:

[T] he obvious and simple system of natural liberty establishes itself of its own accord. Every man, as long as he does not violate the laws of justice, is left perfectly free to pursue his own interest in his own way, and to bring both his industry and capital into competition with those of any other man, or order of men.

Id. 17.

43. Again, for the fuller elaboration, see EPSTEIN, FORBIDDEN GROUNDS, supra note

44. Plessy v. Ferguson, 163 U.S. 537, 559 (1896) (Harlan, J., dissenting):

The white race deems itself to be the dominant race in this country. And so it is, in prestige, in achievements, in education, in wealth, and in power. So, I doubt not, it will continue to be for all time, if it remains true to its great heritage and holds fast to the principles of constitu- 
sure that the state did not use its dominant power to advance the interest of one group over another. We do a great disservice to his memory by overlooking that noble cause.

Thus far I have noted the close analytical connection between the antidiscrimination norm and the presence of monopoly power. The former should be used as an effort to limit the state as well as private use of monopoly power. On this view, however, the antidiscrimination principle has no role to play to the extent that it is invoked to limit the ordinary principle of freedom of association as it applies to those private individuals and firms that do not possess any monopoly power at all. We need to invoke the antidiscrimination principle against the monopolist to protect customers of essential facilities and services, such as the hub of a railroad network, who otherwise have no other place to go. ${ }^{45}$ But once any individual or institution is stripped of that monopoly power, then everyone else finds their strongest protection in the power to go elsewhere if they do not like the terms and conditions on which any one provider chooses to offer some goods or services. Free entry thus becomes the low-cost antidote to discrimination and abuse in competitive settings.

This analysis has powerful implications for the use and reach of the color-blind principle. That principle which is used to prevent the creation of explicit political castes in a constitutional order should yield to the principle of freedom of association once the vestiges of monopoly power have been removed from the playing field. At this point we can see the great structural mistake of the Civil Rights Act of 1964 insofar as it sought to regulate employment and educational opportunities. It demanded that the same color-blind principle that applies to the state in its role of the enforcer of private rights and the operator of social infrastructure be used to regulate the decisions of private actors in competitive markets. In so doing, it injected a new and gratuitous element of monopoly power - the insistence that all private employment contracts abide by a single set of rules dictated by the state. When that statute was passed, most of its supporters made the confident empirical judgment that the consistent application of the nondiscrimination principle in employment and education would lead to an elimination of serious racial differences in the distribution of income and attainment. For whatever reason, it turns out that they were wrong. It was only a matter of a short time until the dominant consensus shifted away from the two-sided nondiscrimination principle in favor of a rule that maintained the hard-edge against discrimination in one direction - against blacks and other racial minorities - while extolling the vir-

tional liberty. But in view of the Constitution, in the eye of the law, there is in this country no superior, dominant, ruling class of citizens. There is no caste here. Our constitution is color-blind.

45. See, e.g., United States v. Terminal R.R. Ass'n, 224 U.S. 383 (1912). 
tues of voluntary affirmative action in the other. In effect, one-half the Civil Rights Act was repealed by the artful construction given to Title VII, which allowed discrimination toward some but not toward others.

The great error was that neither the courts nor the legislature were prepared to finish the job and to recognize that for ordinary private individuals and associations, the freedom of association principle should dominate the color-blind principle rightly invoked by Harlan in Plessy. The benefits of that principle can be quickly restated. The level of public coercion is minimized as individuals are allowed to form those contracts and associations that maximize their joint benefits. They have greater information about who they are and what they want than any legislature or any court, and thus can work out the elaborate personal and institutional arrangements that depend critically on the accumulation of that knowledge. Where the two parties do not agree, then the law provides both with a clear fallback position: each can refuse to deal with the other. Any two people who do form a miniassociation presumptively have it within their power to decide who else gets admitted into their group and who is excluded. The absolute refusal to deal is allowed, indeed encouraged, because other individuals and other groups can fill the social spaces left empty when one group, wisely or stubbornly, follows a policy of exclusion.

So long as the critical ingredient of monopoly power is missing, it hardly matters what the grounds of inclusion and exclusion are. The chess club can exclude checkers players; it does not have to allow into membership anyone who plays board games. So it is that Jews and blacks and Christians and Muslims can all form their own groups, be it for religious, social or political purposes. One nice feature of this system is that it allows for all individuals to assume overlapping identities by taking on multiple memberships. I can be the member of a Jewishonly synagogue, a sports league open to men only, and an eating club open to all comers. The synagogue can invite non-Jews to participate in its athletic programs and after-school activities, but not in its religious instruction. The dense network of crossovers does not respond to any central plan, but emerges by successive interactions of ordinary people. In this milieu, the norm of freedom of association dominates because any effort to have the state decide the grounds on which people may not (or must) be admitted to organizations enlarges the very risk of monopoly power that makes government action so perilous in the first place.

This principle is, moreover, wholly consistent with the constitutional ideal of equal protection of the laws, because it does not work differentially to the advantage of any one racial or religious group. Thus a full-throated endorsement of this principle makes it impossible for any state to exclude those groups who want to admit everyone, regardless of race, creed or religion, except members of the $\mathrm{Ku}$ Klux Klan. The entire course of segregation in the Old South, especially its 
totalitarian excesses, would have been vastly different if segregationist governments had been prepared or required to extend full and equal legal protection to voluntary integrated organizations as they did to segregated ones. The change in local governance would have altered the patterns of entry and exit into the region. The arrival of new people would lead to further changes in political composition of the electorate, and in the long run to the transformation of its ordinary politics. These changes in turn would have led to a major amelioration of social tensions, even if some white southerners had adamantly sought to preserve in their private relations only the traditions of segregation. One controversial conclusion from this position is that the antidiscrimination laws have been extended beyond their proper sphere when used to regulate the behavior of individuals and firms in private competitive markets. To my mind, they are (or at least should be) unconstitutional insofar as they are applied to private voluntary organizations.

\section{Affirmative Action, At Last}

This conclusion is well beyond our comfortable mainstream, and doubtless will offend many. Nonetheless, it offers the ray of hope in sustaining affirmative action and undoing the social mischief that I believe will surely follow if the University of Michigan and other public and private universities are forced by a dubious reading of the equal protection clause into the Procrustean Bed whereby none of them can adopt affirmative action programs. If my analysis is correct, then it explains why the correct interpretation of the color-blind norm prevents the use of official favoritism without, at the same time, touching matters of private associational choice. Today we do live in an age of identity politics. Indeed for much of our history we have had identitybased social movements. ${ }^{46}$ It seems odd beyond all imagination to believe first in the durability and the legitimacy of these movements, only to turn around and conclude that their sole permissible political objective is to secure color-blind rules in circumstances when the application of color-based rules work to their disadvantage. A far more respectful reading of that tradition is to reaffirm the private/public line and to argue that all groups, regardless of their composition, have equal rights under law, including enjoyment of the full rights of association - precisely because they enjoy the equal protection of the laws (and of course liberty of contract under the due process clause as well).

46. For discussion, see William N. Eskridge, Jr., Some Effects of Identity-Based Social Movements on Constitutional Law in the Twentieth Century, $100 \mathrm{MICH}$. L. REV. 2062 (2002) (this issue). 
Those rights of association, I repeat, are not only rights of exclusion. They are also rights of inclusion. In the modern setting, we know how many individuals choose to exercise their rights. In one sense, the Supreme Court beat a hasty retreat from a badly overgeneralized color-blind norm when, in United Steelworks $v$. Weber, ${ }^{47}$ the Court allowed private firms, unions and associations to engage in discrimination that favors African-Americans and other minority groups. However much one may question their wisdom, no one can deny the power, durability and direction of these associational choices. Can anyone name a single institution (other, perhaps, than once all black institutions) that announces a race-based policy against blacks? No. The quick but cynical reply says that this pattern can only be treated as a beneficent consequence of the Civil Rights Act that makes such discrimination illegal. My reaction is exactly the opposite. The moral case for affirmative action is weakened, not strengthened, by the public prohibitions against private discrimination against blacks. That legal barrier makes it all too easy for cynics to argue that the widespread support for affirmative action is simply a clever ploy to reduce the odds being held liable under the Civil Rights Act.

Yet the truth is otherwise. I have no question that tomorrow's repeal of the Civil Rights Acts would not result in the end of affirmative action programs. The current practices cannot be explained as a clever strategy to escape liability. Were that the case, then private institutions would edge as close of the line as they could without being caught. But the dominant reality is otherwise. The level of affirmative action in the United States in the private sector on grounds of race goes far beyond what is needed to keep firms out of hot water. It represents a sustained and consistent effort to change the dominant practices in the United States. It is often said that narrow and atomistic accounts of human nature fail to explain complex problems of social organization. Glenn Loury pushes hard on that point when he attacks the traditional rights-based theories of contractual freedom associated with Robert Nozick. ${ }^{48}$ Yet at no point does he, or others like him, return to the original rhetoric in support of the 1964 Civil Rights Act, where the constant theme was that disembodied merit should be the exclusive criterion on which employment (and similar

\section{443 U.S. 193 (1979).}

48. See Robert Nozick, ANARChy, STATE, AND UTOPIA (1974), criticized in Loury, supra note 23 , at $128,212 \mathrm{n} .5$ (2002). The gist of that criticism is that the theory does not explain what should be done when the transfer of resources in society does not follow the prescribed rules, which in Nozick's case are the rules of original acquisition by capture followed by voluntary transfer thereafter - yet another variation on Smith's system of natural liberty. But no theory works well with restitution from admitted wrongs, especially those from systemic social causes. For different views on this subject, see Orlando Patterson, Beyond Compassion, DAEdalus, Winter 2002, at 26, and Richard A. Epstein, Against Redress, DAEDALUS, Winter 2002, at 39. 
decisions) were made. As Hubert Humphrey stated: "In Title VII we seek to prevent discriminatory hiring practices. We seek to give people an opportunity to be hired on the basis of merit, and to release the tremendous talents of the American people, rather than to keep their talents buried under prejudice or discrimination." ${ }^{49}$ The statute thus did not appreciate the importance that the full range of personal characteristics has for the effective operation of voluntary markets, and thus has created a caricature of hiring standards that dogs the operation of labor markets to this day. The civil rights establishment, so keenly attuned to the dangers of Jim Crow, was blind to the long-term effects of Title VII. Loury and others should direct their fire against the civil rights establishment and not the market libertarians, who avoid the mistake of limiting employment decisions behind some public standard of merit..$^{50}$

It is not just black intellectuals and libertarians who get the point. Many white people hold the same views with passionate intensity. The level of affirmative action in the United States is not explainable by pressure from minority groups alone. They are too weak to do the job. White support for these programs is needed to explain the variegated responses to the use of affirmative action in the United States.

This combination of past history and present practice gives us the vital clue as to the proper role of government with respect to the affirmative action challenge. The public/private distinction of classical liberal theory has become blurred because governments today do more than classical liberals like myself think appropriate. One of the things that states do, which probably they should not do, is run great universities. But here is not the place to argue for the privatization of state universities. ${ }^{51}$ Nor is it any part of my agenda to invoke the colorblind standard as a backhanded effort to induce state universities to privatize. Rather I shall undertake only the more limited task of determining how the state should be judged when it steps beyond its traditional nightwatchman's role and undertakes the kinds of enterprises that are also taken by private institutions in competitive markets. Here we must inescapably make judgments about the operation of a secondbest world. Ultimately the question is one of resemblance. Do public universities and their kindred institutions look more like private institutions that supply the same sorts of educational services, or do they look more like the arms of the system of law enforcement?

49. 110 CONG. REC. 6548 (1964). 163-65.

50. For my views, on the point, see Epstein, FORBIDDEN GROUNDS, supra note 17, at

51. Adam Smith may have been a bit harsh when he wrote: "Were there no public institutions for education, no system, no science would be taught for which there was not some demand; or which the circumstances of the times did not render it either necessary, or convenient, or at least fashionable, to learn." SMITH, supra note 41 , at 733 . 
In my view, the answer to that question is clear: the private analogy wins, hands down. State universities receive some public funds, and are subject to too much direct legislative control. But they charge tuition for the students who they enroll, and they pay salaries to the faculty and administrators that they hire. In both settings they operate in intensely competitive markets, where the competition comes from a wide array of private institutions, from state institutions within the state, and from state institutions of other states.

That context matters. No one to my knowledge thinks that a demand for an affirmative action program is even intelligible when the state operates in its law enforcement capacity. No one claims that an affirmative action law should allow black individuals to escape on grounds of race punishment for actions that expose white individuals to charges of murder. No one thinks that the punishment to all blacks should be 1.2 or 0.8 times the same punishment for whites for the same offense under the same circumstances. Even if we think that raceconscious decisions should be used in hiring and assigning members of the police force - and in many cases we do - the goal is always to secure all individuals the equal protection of the laws, with the emphasis evenly distributed between "equal" and "protection."

Yet matters take on a different aspect when we deal with the distribution of government benefits through state run firms in competitive markets. We need in these cases a benchmark to decide what is and is not appropriate behavior. All too often the tendency in dealing with matters of race is to decry the use of private law analogies in setting out the standards in these cases. Kimberle Williams Crenshaw has taken just that route when she argues that Lochner v. New York ${ }^{52}$ is cut from the same cloth as is Plessy and should therefore be denounced for the same reasons we denounce Plessy. ${ }^{53}$ One obvious difference between the two cases should give pause to that conclusion. Plessy opted for a very broad definition of the police power, which allowed for the separation of the races on the supposed grounds that it would advance the purpose of racial harmony. Lochner, for its part, hewed to a narrower definition of the police power to strike down a state that prevented certain classes of bakers from working more than ten hours per day on the ground that this ostensible safety statute was really little more than a disguised labor law (i.e., an explicit anticompetitive statute).

I cannot resist mentioning one obvious irony here. To the extent that Plessy could be read (in modern terminology) to adopt a rational basis standard for racial classification, every defender of affirmative action should devoutly wish that it were the authoritative decision in

52. 198 U.S. 45 (1905).

53. Kimberlé Williams Crenshaw, Address at the Michigan Law Review Centennial Celebration (Feb. 16, 2002). 
Gratz and Grutter. At this point the University of Michigan wins the case in a walk. But this line of argument seems perverse if read to legitimate the actual legal outcomes in Plessy itself.

The key to the puzzle lies in setting the context for both Plessy and Lochner. Both of these cases involved claims for state interference with private organizational preferences. In both cases the state overstepped its nightwatchman role, and in both cases its actions should have been struck down. Lochner was right, and Plessy was wrong. But our context is different. Here the state is acting as a market participant not as a regulator. We still have to worry about the illicit use of state power, but now we have a benchmark against which we can check its action. Quite simply, we take as the measure of the reasonableness of the state action the question of whether it follows the voluntary patterns and choices made by the private institutions with which it competes. Here, it is clear that no private institution will practice explicit racial discrimination against blacks. We therefore do not have to worry about the occasional ambiguity if some small but respectable fraction of private institutions did follow this practice. Quite simply, state institutions may be constrained to act within a narrower band of reasonableness than private institutions. But no matter how that question is resolved, no state institution can adopt positions that are more extreme than those of the private benchmarks against which its behavior is judged. We do not have to embrace the alarmist position that the acceptance of affirmative action programs opens the door to traditional forms of race segregation in higher education. By the same token, (notwithstanding the presence of the Civil Rights legislation) we know that these organizations strongly endorse some practice of affirmative action.

We may rest assured, moreover, that they reached these decisions after they heard each and every argument that could be raised in defense of a color-blind principle in social life. These institutions are fully aware of the limitations of standardized tests, for they rely on them to choose applicants within separate cohorts. They understand the danger of stigma that comes from the use of affirmative action programs - and the danger of stigma that comes from their elimination. (Stigma is one of those ubiquitous if elusive vices that can be thrown up in the face of any social program, regardless of content or motive, that addresses the problems of race.) They are fully aware that it is more expensive to recruit and retain minority students in their ranks. They know that the acceptance of minority students will necessarily displace white students with superior academic credentials. They have figured out that you cannot get sufficient minority representation into private and public universities by jiggering any set of race-neutral standards in ways that maximize black representation. They understand that in some ways it is more difficult to teach classes in which students come with widely different levels of academic skills. They 
know full well that remedial education for minority students (or indeed all underprivileged students) has only an uncertain success rate. They are aware that minority students finish on average lower in classes, take longer to finish their degrees, and have a higher drop out rate. They know that the aggressive recruitment of minority students means that across the board, they have lower academic achievement levels than their peers.

These findings are not news. In many cases these objections have real bite. They may, and should, influence the resources devoted to affirmative action programs. They may supply pointers as to how these programs should be run; they may offer clues as to why some programs succeed while others flounder. But throughout it all, the vast bulk of private institutions of higher education in the United States remain steadfast in their use affirmative action programs. Their public competitors should have the same options available to them.

In my view, this point is critical to assess the constitutionality of the overall system. I do not think that the Constitution should be read to allow the state to meet the minimal standards in traditional rational basis analysis in deciding on its racial practices. That lax standard would allow a state to reinstitute programs of discrimination against blacks even if no private organizations followed that pattern, contrary to the position I have taken above. Nor do I think that this position requires one to jettison Brown v. Board of Education ${ }^{54}$ in order to salvage modern affirmative action programs. Those programs could not have survived in their traditional form if blacks had equal rights of participation in the political process and were not subjected to the rein of intimidation and terror, private and official, that characterized so much of organized segregation in the Old South.

Yet none of those conditions apply today. Instead we can say with some confidence that this case should be governed by a constitutional variation of the business judgment rule. Members of boards of trustees, university presidents, provosts, deans, faculty, and students have concluded through their internal deliberations that affirmative action programs are an essential ingredient to their overall programs. No one should override a private organization that takes that stand. Most legislators don't have the foggiest idea of how private universities are run, and they should keep their hands out of the pie. In this regard, the passage of Proposition $209^{55}$ in California represents just the wrong approach because it seeks to impose a top-down, system-wide response, which only exposes the dangers of state monopolies. The hostile response from below shows just how unwise it was for the California voters to adopt this form of command-and-control activi-

54. 347 U.S. 483 (1954).

55. CAL. CONST. art. 1, § 31 (adopted 1996). 
ties. Decentralized decisions, with minimal legislative intrusion, are surely the order of the day. A similar vice, with similar drastic consequences follows from the passage of Title IX, dealing with sex discrimination in aid to higher education; its instant repeal is a good place to reform federal policies. What is true of legislators is true of judges and justices (even those who come from academic backgrounds). They could not run a university either, at least on the color-blind principles that they could impose under a misplaced reading of the Equal Protection Clause.

The question that remains is how far am I prepared to go with the ideal of freedom of association. Thus one sensible challenge asks whether or not I would allow state educational institutions to adopt an explicit religious profile as say, a Baptist, Catholic or Jewish institution. There is no question that such a decision would be regarded today as a per se violation of the Establishment Clause. ${ }^{56}$ Private universities can fill this particular void. Public universities need not.

In my view sectarian public institutions of this sort should be regarded as out of bounds. The question is how to distinguish this case from that of affirmative action. Here I think that the best line of attack is to note the three major approaches towards religion: separation, accommodation, and neutrality. ${ }^{57}$ None of these finds any place for staterun religious institutions, but they differ strongly in the way in which they respond to religious activities in public universities. It is easy, too easy, for the strict separationist to hold that no state university should tolerate any religious activities on campus. That position strikes me as untenable precisely because private secular universities all make place for Christian, Jewish and Muslim organizations in their ranks, and regard themselves as the stronger for it. I am hard pressed to see why public institutions have to be barren on matters of such evident importance, especially in an age of identity politics. All in is far better than all out.

But all in on what terms? In most cases that will require simply neutrality, so that a university decision to fund nonreligious campus magazines, for example, means that the state must also fund religious magazines out of revenues drawn from all students. ${ }^{58}$ But this nondiscrimination approach does not necessarily require a principle of neutrality toward religion in all cases. Ever since the decision in Employment Division, Department of Human Resources v. Smith, ${ }^{59}$

\footnotetext{
56. U.S. CONST. amend. I.
}

57. For discussion, see Michael McConnell, Accommodation of Religion, 1985 SUP. CT. Rev. 1; Philip Kurland, Of Church and State and the Supreme Court, 29 U. CHI. L. REv. 1 (1961) (advocating strict neutrality), and Douglas Laycock, The Underlying Unity of Separation and Neutrality, 46 EMORY L.J. 43 (1997).

58. Rosenberger v. Rector, 515 U.S. 819 (1995).

59. 494 U.S. 872 (1990). 
which refused to make any accommodation for those who smoked peyote only for religious purposes, strict neutrality has rightly been under attack across the political spectrum. ${ }^{60}$ In this context, some accommodation should be made, as it routinely is, for men who wear yarmulkes or women who for religious reasons will not shake hands with men (as on receipt of their degrees). The exact extent to which accommodation tempers a belief in neutrality is one of the hardest questions in the vexed law of religious liberty, but the details of that tradeoff need not bother us here. All that we need do is affirm the view that inclusion of all religious life on campus is part of the picture, while leaving it to a later day to work out the details on how it should be done.

Stated otherwise, the current practices on religion within the university seem to recognize the difference between the state in its role as nightwatchman and the state in its role as provider of goods and services. There is no real demand for public institutions to adopt explicit religious postures. There is no need in a public university to tolerate the exclusion of members of other religious groups. The establishment clause has much more direct bite than the equal protection clause, and any justification for deviation from that principle seems quite weak given the wide range of faiths and religions from which public universities draw. Their varying needs can be met by sensible open access for all that makes, at the edges, appropriate accommodations for first this group, and then that one. ${ }^{61}$ The matter is not free from doubt of course. It is also possible to take the position that we should allow these religious campuses to develop under state auspices because the diffusion of political power is such that no one faith would get to run all such campuses. But I think that the risk of serious social dislocation is large enough relative to the dubious gains that are generated that we should leave well enough alone on this front. The rules on religious activities in public universities can stay more or less where they are.

It is useful to sum up: public institutions of higher education are in close competition with private institutions of higher education. It simply defies imagination (to lapse into Scalia-like excesses) ${ }^{62}$ to think that they should be disabled from adopting and following the same strategies as their private competitors on affirmative action questions.

60. See City of Boerne v. Flores, 521 U.S. 507 (1997) (striking down the Religious Freedom Restoration Act, 42 U.S.C. $\$ \S 2000$ bb-1 to - 4 (1994)). I think that Boerne was correctly decided insofar as it affirmed the dominance of the Court over Congress in setting constitutional standards. But that is only one reason why Smith should be overruled.

61. Thus the believer in strict neutrality would allow a prohibition on all headgear if done for nonreligious reasons. But surely an accommodation that allowed religious headgear should be allowed in classes absent some clear showing as to why it is inappropriate. But these details do not influence the general point here.

62. For typical examples, see Erwin Chemerinsky, The Rhetoric of Constitutional Law, 100 MICH. L. REV. 2008 (2002) (this issue). 
For these purposes, they should be regarded as voluntary associations, and as such be protected against constitutional attack precisely because they are seeking to implement the principle of freedom of association within the public sphere. Think back to the tests for using the strict scrutiny in the first place. Here we have a powerful independent check, which explains why affirmative action programs are adopted. Private institutions of all sorts and stripes use them. The state universities that adopt them are not dominated by one narrow group. The political constellation of forces looks exactly like that which inspired (wrongly in my view) the rational basis test for the state regulation of private actors. The story on substance is much the same.

\section{Dialogue}

There is one question that remains. How will various universities seek to manage the question of affirmative action if and when the Supreme Court decides that it is best to allow business as usual to proceed without the cloud of constitutional invalidation? In my view, it should improve the situation. One great vice of the current debate is how it polarizes positions. There is no give whatsoever in the colorblind position. Race has to be ignored in all ways and at all times. Any deviation from the principle becomes a mortal sin. But oddly enough, the situation is scarcely better if we switch to the other side and proclaim that the case for affirmative action is so compelling that it meets the strict scrutiny standard set up under the equal protection clause. Let that be the case, and how can any hardy soul argue against the principle in practice? Is it really tenable to take a public position to eliminate or even restrict a program that the Supreme Court has found to be a high social imperative?

These two extreme positions create a battle of the titans. But unfortunately, they drag down everyone who hopes to adopt some moderate position to the ever-momentous problems of race. But the social success in dealing with the race issue in America depends on our ability to defuse the passions that the topic so typically raises. No sensible administrator in a regulation-free world would ever wish to debate affirmative action in the grandiose terms that dominate public discourse. Rather, the only strategy that works is one that adopts some position more favorable to affirmative action than its staunchest opponents would allow, but less favorable to its invocation than its faithful supporters demand. At every point, the grand debate is put into the background so that smaller issues can prevail. How do this year's numbers look relative to last year's? What is the relative strength of the different groups in the pool? What is the public reputation of the school? What is the position of the alumni? How does the affirmative action program tie in or relate to other initiatives in the institution? At each juncture, the key is to make those incremental adjustments in the pro- 
gram in order to achieve what are in the end only incremental improvements. Affirmative action becomes a management priority: get through this year with good relations and trust, and then try to do a bit better next year. I can of course give no concrete advice to the University of Michigan on how it should configure its program unless asked. But I do have advice for those who are sure that they know how to run the venture from afar. Cool it on the big think. Small steps do best, in an environment that is free of constitutional impediments. 